\title{
GAS1 Gene
}

National Cancer Institute

\section{Source}

National Cancer Institute. GAS1 Gene. NCI Thesaurus. Code C106451.

This gene plays a role in cell growth suppression. 